\title{
PEMBELAJARAN RME (REALISTIC MATEMATICS EDUCATION) TERHADAP KEMAMPUAN BERPIKIR KREATIF MATEMATIK PADA SISWA SMP
}

\author{
Wahyu Hidayat ${ }^{1}$, Koentri Jayanti ${ }^{2}$, Ilfa Febrina Nurismadanti ${ }^{3}$, Muhammad Zulfikar \\ Ikhsanuddin Akbar ${ }^{4}$, Kholifia Ayuning Pertiwi ${ }^{5}$, Pusparini Rengganis ${ }^{6}$ \\ IKIP Siliwangi, Jalan Terusan Jenderal Sudirman, Cimahi \\ ${ }^{1}$ wahyu@ikipsiliwangi.ac.id, ${ }^{2}$ koentrijayanti26@gmail.com, ${ }^{3}$ ilfafebrinan00@gmail.com, \\ 4zulfikar160497@gmail.com, ${ }^{5} @$ kholifiapertiwi452@gmail.com, ${ }^{6}$ pusparinirengganis@gmail.com.
}

\begin{abstract}
This research aims to look at the difference in the ability of mathematical creative thinking in students, through Realistic Mathematical Education learning or RME and through conventional learning. The research design used was an experiment, namely in the form of a test of the ability of creative thinking. The population in this study of Junior High School students throughout the country, namely in West Bandung Regency. Sample research VIII grade i.e. in one of the Junior High School in West Bandung chosen at random and selected class A (grade experiment) that uses learning Realistic Mathematics Education (RME) and class B (grade control) that uses regular or conventional learning. The research results showed that the p-value of $0.000<$ critical limits. Thus, the ability of mathematical creative thinking of the students who got the learning with Realistic Mathematics Education better than the students who got conventional learning.
\end{abstract}

Keywords: Realistic Mathematic Education (RME), The ability of creative thinking

\begin{abstract}
Abstrak
Penelitian ini bertujuan untuk melihat perbedaan kemampuan berpikir kreatif matematik pada siswa, melalui pembelajaran Pendidikan Matemaik Realistik atau RME dan melalui pembelajaran konvensional. Desain penelitian yang digunakan adalah eksperimen, yaitu berupa tes kemampuan berpikir kreatif. Populasi dalam penelitian ini yaitu seluruh siswa SMP Negeri di Kabupaten Bandung Barat. Sampel penelitian yaitu siswa kelas VIII di salah satu SMP di Bandung Barat yang dipilih secara random dan dipilih kelas A (kelas eksperimen) yang menggunakan pembelajaran Realistic Mathematics Education (RME) dan kelas B (kelas kontrol) yang menggunakan pembelajaran biasa atau konvensional. Hasil penelitian menunjukan bahwa $p$ value sebesar $0,000<$ batas kritis. Maka, kemampuan berpikir kreatif matematik siswa yang mendapat pembelajaran dengan RME lebih baik dari pada siswa yang mendapat pembelajaran konvensional.

Kata Kunci : Realistic Mathematic Education (RME), Kemampuan Berpikir kreatif

How to cite: Hidayat, W., Jayanti, K. Nurismadanti, I. L., Akbar, M. Z. I., Pertiwi, K. A., \& Rengganis, P. (2018). Pembelajaran RME (Realistic Matematics Education) terhadap Kemampuan Berpikir Kreatif Matematik pada siswa SMP. JPMI - Jurnal Pembelajaran Matematika Inovatif, 2 (1), 41-50.
\end{abstract}

\section{PENDAHULUAN}

Pendidikan merupakan hal yang sangat penting, baik pendidikan formal maupun pendidikan nonformal. Pendidikan formal diperoleh di sekolah, sedangkan pendidikan nonformal dapat 
diperoleh dimana saja (sekolah, rumah, atau lingkungan sekitar). Saat di sekolah, perlu adanya pengembangan kemampuan-kemampuan pada diri siswa. Salah satu kemampuan yang sangat penting sehingga harus dikembangkan yaitu kemampuan berpikir kreatif matematik. Arifin \& Purwasih (Andiyana, Maya, \& Hidayat, 2018) mengemukakan bahwa dilihat dari pengkategorian bidang ilmu pengetahuan, mata pelajaran matematika tergolong ke dalam ilmu pasti yang lebih banyak membutuhkan berpikir kreatif dari pada hapalan. Dengan berpikir kreatif siswa dapat mengetahui adanya permasalahan-permasalahan dan akan dapat dengan mudah mengkomunikasikan atau mengungkapkan apa yang siswa pikirkan. Sejalan dengan pendapat (Choridah, 2016) sekolah adalah salah satu tempat dimana peserta didik menimba ilmu pengetahuan, mengembangkan seluruh bakat serta keterampilan yang dimilikinya, dan tempat untuk menyalurkan ide-ide brilian sebagai bagian dari proses berpikir kreatif. Kemampuan berpikir kritis dan kreatif adalah satu hal yang sangat penting dalam masyarakat modern, karena dapat membuat manusia menjadi lebih luwes secara mental, terbuka dan mudah menyelaraskan dengan beragam situasi dan persoalan (Hidayat, 2012).

Berdasarkan penelitian yang telah dilakukan oleh Wijayanti (2017) siswa mengalami masalah prestasi belajar yang kurang memuaskan, yaitu terlihat dari hasil belajar yang dibawah KKM. Hal ini dikarenakan: (1) Dalam pembelajaran siswa cenderung pasif dan tidak berani bertanya; (2) Apabila diberikan soal, hanya siswa tertentu yang termotivasi untuk mengerjakan soal; (3) Apabila terdapat permasalahan yang bersifat abstrak, siswa belum bisa menghubungkan pada hal kongkrit yang ada disekitar lingkungan siswa; (4) Siswa hanya mengerjakan soal dengan jawaban yang sama tidak berani mencoba dengan cara lain. Dari masalah tersebut siswa terlihat kurang berminat dalam belajar matematika, sehingga kreativitas siswa pun kurang terbentuk dan berkembang. Oleh karena itu, dalam mengembangkan dan meningkatkan kemampuan berpikir kreatif siswa, guru hendaknya menciptakan pembelajaran yang kondusif.

Dari permasalahan tersebut, Sumarmo, Hidayat, Zukarnaen, Hamidah, \& Sariningsih, (2012) mengemukakan bahwa pengembangan kemampuan berpikir matematik tingkat tinggi seharusnya lebih diutamakan untuk inti matematika yang esensial dan disertai dengan materi ajar dan kontribusi guru yang sesuai dengan kebutuhan siswa, salah satunya dengan pembelajaran Realistic Mathematics Education (RME). Menurut Wijaya (Indraningtias \& Wijaya, 2017), matematika merupakan suatu bentuk aktivitas manusia melandasi pengembangan Pendidikan Matematika Realistik (RME). Dari peryataan tersebut terlihat bahwa matematika tidak dberikan secara langsung begitu saja melainkan siswa harus dapat mengkontruksi sendiri pengetahuannya, melalui masalah yang bersifat kontekstual. Dalam proses pembelajaran realistic mathematics, pembelajaran diawali dengan sesuatu yang nyata agar siswa dapat turut aktif dalam pembelajaran secara bermakna. Siswa dituntut untuk membangun pengetahuan dengan kemampuannya sendiri. Pembelajaran matematika harus difokuskan pada pengaplikasian yang berhubungan dengan kehidupan sehari-hari, sesuai dengan tingkat pengetahuan dan kemampuan yang dimiliki siswa. Peran guru hanya sebagai seorang fasilitator dan pembimbing dalam proses rekonstruks konsep pembelajaran matematika.

Menurut (Hadi, 2017), dalam PMR (RME) siswa tidak dapat dipandang sebagai botol kosong yang harus diisi dengan air. Siswa hendaknya diberikan kesempatan untuk menemukan kembali konsep matematika dengan bantuan guru, yaitu dengan menyelesaikan berbagai masalah kontekstual diawal pembelajaran. Berdasarkan hal tersebut, peneliti akan mengkaji tentang perbedaan pencapaian kemampuan berpikir kreatif matematik siswa yang menggunakan pembelajaran RME dengan siswa yang menggunakan pembejaran konvensional. Penelitian ini berfokus pada materi Statistika di SMP Kelas VIII. 


\section{METODE}

Peneltian ini merupakan penelitian yang bersifat kualitatif, sedangkan metode yang digunakan yaitu eksperimen. Sekolah Menengah Pertama Negeri (SMPN) di Kabupaten Bandung Barat merupakan populasi dari penelitian ini. Sampel yang digunakan diambil secara acak dan kemudian terpilih kelas A (kelas eksperimen) yang menggunakan pembelajaran Realistic Mathematics Education (RME) dan kelas B (kelas kontrol) yang menggunakan pembelajaran konvensional.

Instrumen yang digunakan yaitu berupa soal tes kemampuan berpikir kreatif matematik sesuai dengan indikator. Prosedur pengumpulan data yang direncanakan peneliti adalah tahap persiapan, tahap pelaksanaan, dan tahap pengolahan data setelah melaksanakan penelitian. Teknik pengumpulan data yang dilakukan dalam penelitian ini adalah dengan dua cara yaitu observasi dan tes.

\section{HASIL DAN PEMBAHASAN \\ Hasil}

Penelitian ini menggunakan dua perlakuan yaitu perlakuan terhadap kelas eksperimen yang mendapatkan RME dan kelas kontrol yang mendapatkan pembelajaran konvensional. Penelitian ini dilakukan untuk mengetahui perbandingan kemampuan berpikir kreatif siswa dalam pembelajaran matematika antara siswa yang mendapatkan pembelajan dengan RME dengan yang mendapatkan pembelajaran konvensional.

Untuk mengetahui perbandinggan kemampuan berpikir kreatif, maka kelas eksperimen diberikan pembelajaran RME dan kelas kontrol diberikan pembelajaran konvesional pada materi Statistika. Setelah pemberian pembelajaran Statistika selesai, diberikan tes akhir (Posttest), dengan tujuan untuk mengetahui perbandingan kemampuan berpikir kreatif matematik yang dimiliki oleh kelas kontrol dengan kelas eksperimen. Berdasarkan hasil penelitian, diperoleh data sebagai berikut:

Tabel 1. Uji Normalitas Postes Eksperimen dan Kontrol

\begin{tabular}{|c|c|c|c|c|c|c|c|c|}
\hline & \multirow{2}{*}{ Kelas } & \multicolumn{3}{|c|}{$\begin{array}{l}\text { Kolmogorov- } \\
\text { Smirnov }^{a}\end{array}$} & \multicolumn{3}{|c|}{ Shapiro-Wilk } & \multirow{2}{*}{ Kesimpulan } \\
\hline & & $\begin{array}{c}\text { Statisti } \\
c\end{array}$ & $d f$ & Sig. & $\begin{array}{c}\text { Statisti } \\
c\end{array}$ & $D f$ & Sig. & \\
\hline \multirow{2}{*}{$\begin{array}{c}\text { Nila } \\
\text { i }\end{array}$} & 1,00 & , 133 & 29 & ,199 & ,951 & 29 &, 195 & Berdistribusi Normal \\
\hline & 2,00 &, 180 & 36 &, 005 & ,948 & 36 &, 088 & $\begin{array}{c}\text { Tidak berdistribusi } \\
\text { Normal }\end{array}$ \\
\hline
\end{tabular}

Berdasarkan tabel 1 diatas, dengan menguji uji kolmogrov-Smirnov diperoleh nilai signifikasi postes kelas eksperimen 0,199 karena $\geq 0,05$ maka $\mathrm{H}_{0}$ diterima, ini berarti nilai postes kelas eksperimen berdistribusi normal. Sedangkan nilai signifikasi postes kelas kontrol 0,005 karena $<\alpha=0,05$ maka $\mathrm{H}_{0}$ ditolak, ini berarti nilai postes kelas kontrol tidak berdistribusi normal. Dikarenakan kelas kontrol tidak berdistribusi normal, maka digunakan uji nonparametrik berupa uji Mann Whitney untuk menunjukkan apakah $\mathrm{H}_{0}$ diterima atau tidak. 
Tabel 2. Uji Homogenitas Varians Postes Eksperimen dan Kontrol

\begin{tabular}{|c|c|c|c|c|c|}
\hline & & $\begin{array}{l}\text { Levene } \\
\text { Statistic }\end{array}$ & $d f 1$ & $d f 2$ & Sig. \\
\hline \multirow{4}{*}{ Nilai } & Based on Mean & 1,090 & 1 & 63 & ,300 \\
\hline & Based on Median & ,874 & 1 & 63 & ,353 \\
\hline & $\begin{array}{l}\text { Based on Median and } \\
\text { with adjusted df }\end{array}$ & ,874 & 1 & 52,175 & ,354 \\
\hline & Based on trimmed mean & 1,043 & 1 & 63 & ,311 \\
\hline
\end{tabular}

Tabel 2, menunjukan hasil uji homogenitas menggunakan metode Levenes's test. Uji Levence digunakan untuk menguji homogenitas varians pada data yang tidak berdistribusi normal. Nilai uji Levenes 's test ditunjukkan pada baris nilai Based On Mean, yaitu dengan Sig ( $p$ value) 0,300 $>0,05$ yang berarti varians kedua kelompok sama atau yang disebut homogen. Maka, syarat homogenitas telah terpenuhi. Terakhir kita akan menguji hiptotesis yaitu dengan uji Mann Whitney U test.

Tabel 3. Uji Hipotesis Mann Whitney Postes

\begin{tabular}{ccc|c|c}
\hline \multirow{2}{*}{ Kelas } & $\mathrm{N}$ & Mean Rank & Sum of Ranks \\
\hline \multirow{2}{*}{ Nilai } & 1,00 & 29 & 44,95 & 1303,50 \\
\cline { 2 - 5 } & 2,00 & 36 & 23,38 & 841,50 \\
\cline { 2 - 5 } & & & & \\
\hline
\end{tabular}

Tabel 3, di atas menunjukkan Mean Rank atau rata-rata peringkat tiap kelompok.

Tabel 4. Test Statistics

\begin{tabular}{cc}
\hline & Nilai \\
\hline Mann-Whitney $U$ & 175,500 \\
\hline Wilcoxon $W$ & 841,500 \\
\hline$Z$ & $-4,596$ \\
\hline $\begin{array}{c}\text { Asymp. Sig. (2- } \\
\text { tailed) }\end{array}$ &, 000 \\
\hline
\end{tabular}

Tabel 4, menunjukkan nilai U sebesar 175,5 dan nilai W sebesar 841,5. Apabila dikonversiikan ke nilai $\mathrm{Z}$ maka besarnya $-4,596$. Nilai sig atau $P$ value sebesar $0,000<$ batas kritis 0,05 maka $\mathrm{H}_{0}$ ditolak. Karena $\mathrm{H}_{0}$ ditolak maka $\mathrm{H}_{\mathrm{A}}$ diterima dan berarti terdapat perbedaan bermakna antara dua kelompok. 


\section{Pembahasan}

Salah satu jawaban siswa kelas ekserimen dan kelas kontrol pada nomor 1, dengan mengidentifikasi ukuran data (Median, Mean, dan Modus) yang mendapat skor terbesar, disajikan pada gambar 1a dan $1 \mathrm{~b}$.

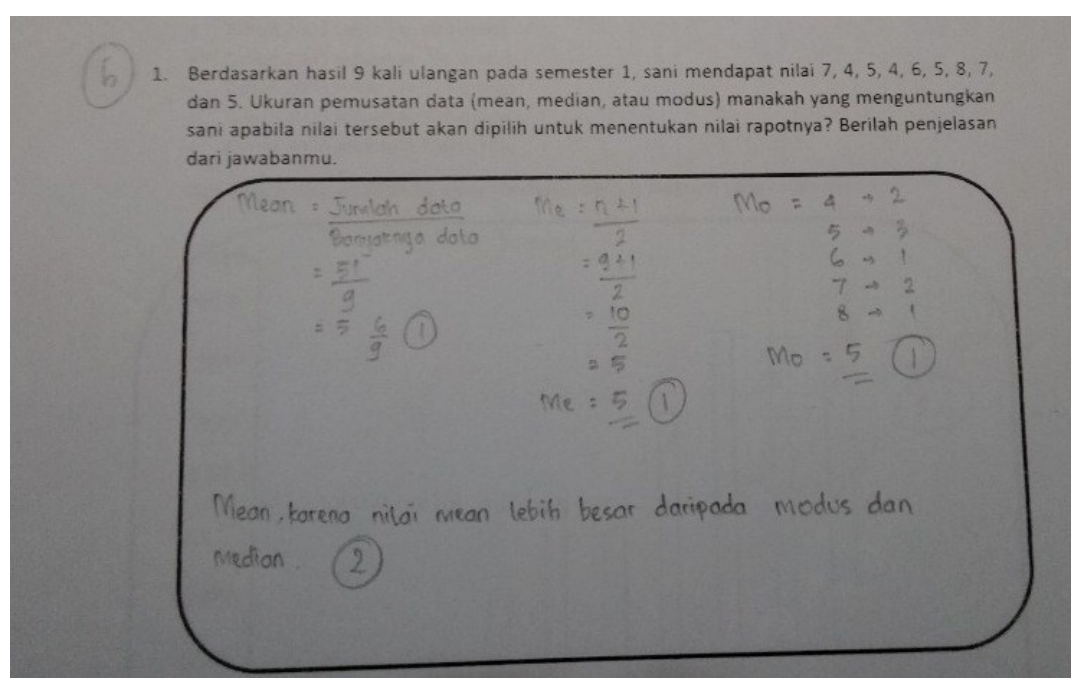

Gambar 1a. Jawaban Siswa Kelas Ekserimen

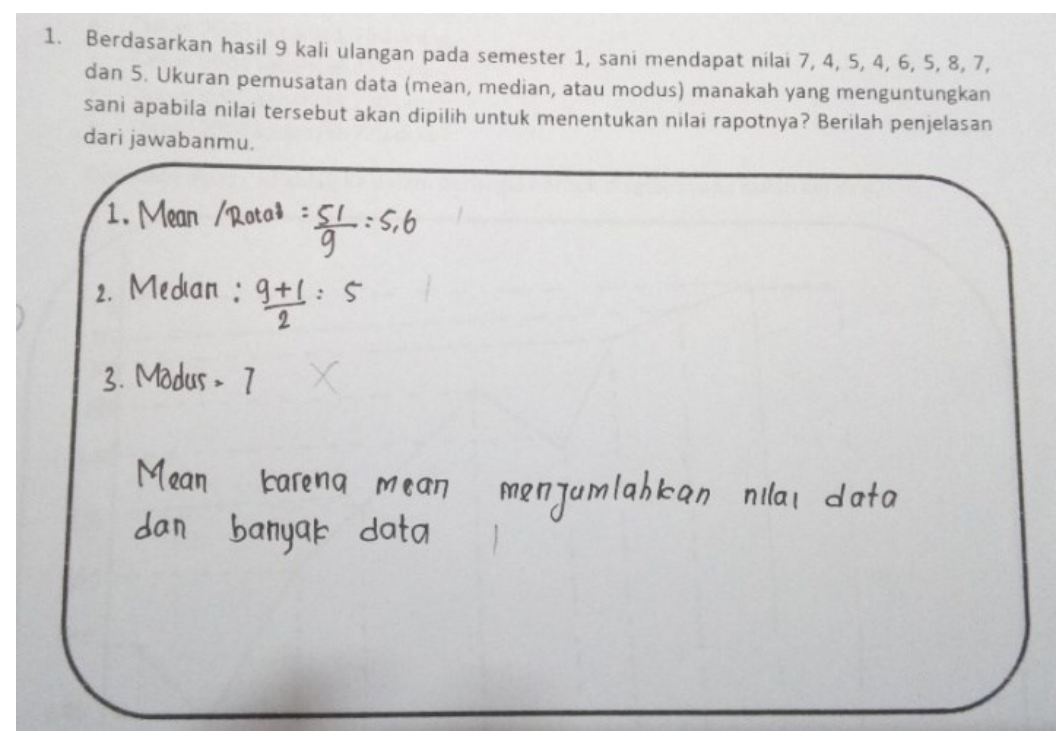

Gambar 1b. Jawaban siswa kelas kontrol yang mendapatkan pembelajaran konvensional.

Pada gambar 1a, jawaban salah satu siswa kelas ekserimen yang mendapatkan pembelajaran RME (Realistic Matematics Education), siswa tidak memiliki kesulitan untuk menentukan nilai Mean (rata-rata), Median, dan Modus. Untuk menentukan jawaban paling besar dan memberikan alasan dari jawabannya pun tidak memiliki kesulitan serta menjawab secara sistematik. Sedangkan pada gambar 1b, jawaban salah satu siswa kelas kontrol yang mendapatkan pembelajaran konvensional, dalam menjawab dan menentukan nilai Mean (ratarata), Median siswa tidak memiliki kesulitan. Namun, pada saat menjawab dan menentukan nilai Modus mereka mengalami kesulitan, dalam menjawab nilai modus mereka salah dalam menghitung banyak masing-masing data. Untuk menentukan jawaban paling besar dan memberikan alasan dari jawabannya tidak mengalami kesulitan tetapi karena nilai Modusnya yang salah maka jawabannya tidak sistematik. 
Salah satu jawaban siswa kelas ekserimen dan kelas kontrol pada nomor 2, dengan mengidentifikasi mencari nilai $x$ yang sudah diketahui datanya, disajikan pada gambar $2 a$ dan $2 b$.

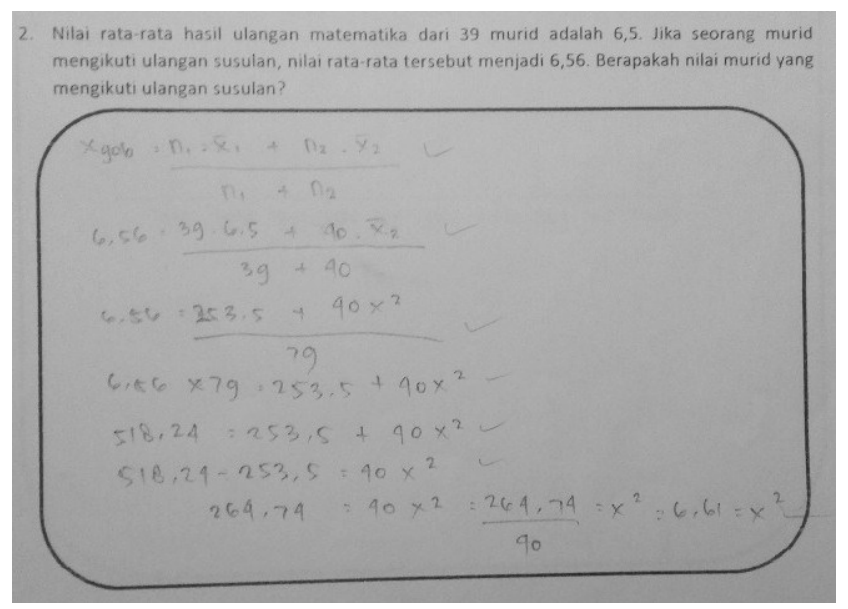

Gambar 2a. Jawaban siswa kelas ekserimen

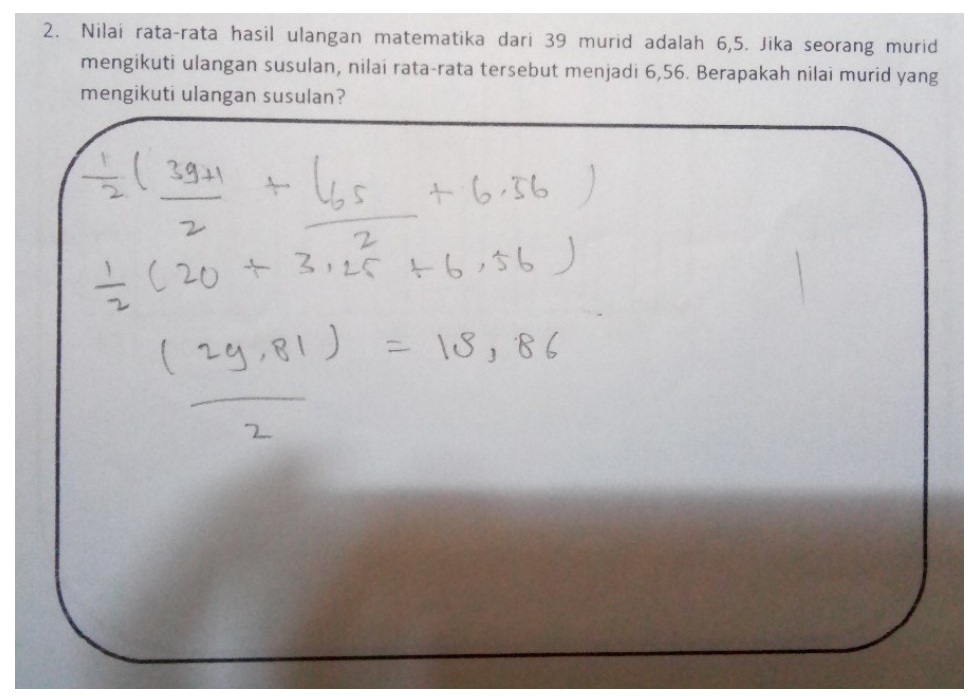

Gambar 2b. Jawaban siswa kelas kontrol

Pada gambar 2a, jawaban salah satu siswa kelas ekserimen tidak memiliki kesulitan untuk menentukan $x$ gabungan, untuk mencari nilai $x$ nya. Dalam menuliskan diketahuinya sudah tepat (dalam menentukan nilai dari $n_{1}, n_{2}$, dan $x_{1}$ nya). Sedangkan pada gambar $2 \mathrm{~b}$, salah satu siswa kelas kontrol mengalami kesulitan dalam menjawab pertanyaan nomor 2. Dalam penyelesaiannya, siswa sudah mencoba menjawab dengan benar tetapi rumus yang digunakan tidak tepat, sehingga membuat jawaban siswa menjadi salah dan siswa tidak menyelesaikan pengerjaannya.

Salah satu jawaban siswa kelas Ekserimen dan kelas kontrol pada nomor 3, dengan mengidentifikasi sebuah data yang harus diubah menjadi berbagai macam diagram yang di ketahui seperti diagram garis, diagram batang dan diagram lingkaran, disajikan pada gambar $3 \mathrm{a}, 3 \mathrm{~b}, 3 \mathrm{c}, 3 \mathrm{~d}$ dan $3 \mathrm{e}$. 


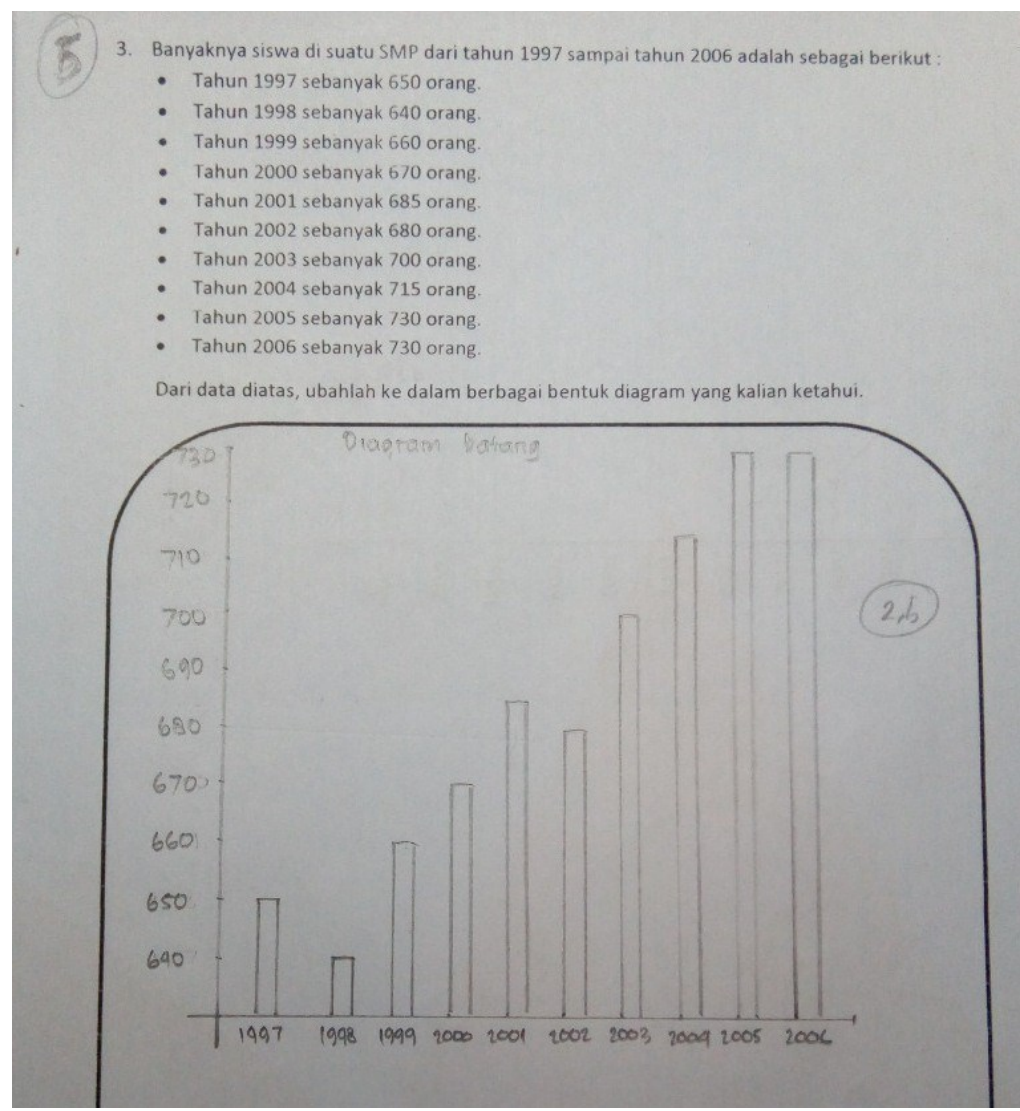

Gambar 3a. Jawaban siswa kelas Ekserimen yang mengerjakan menggunakan diagram batang.

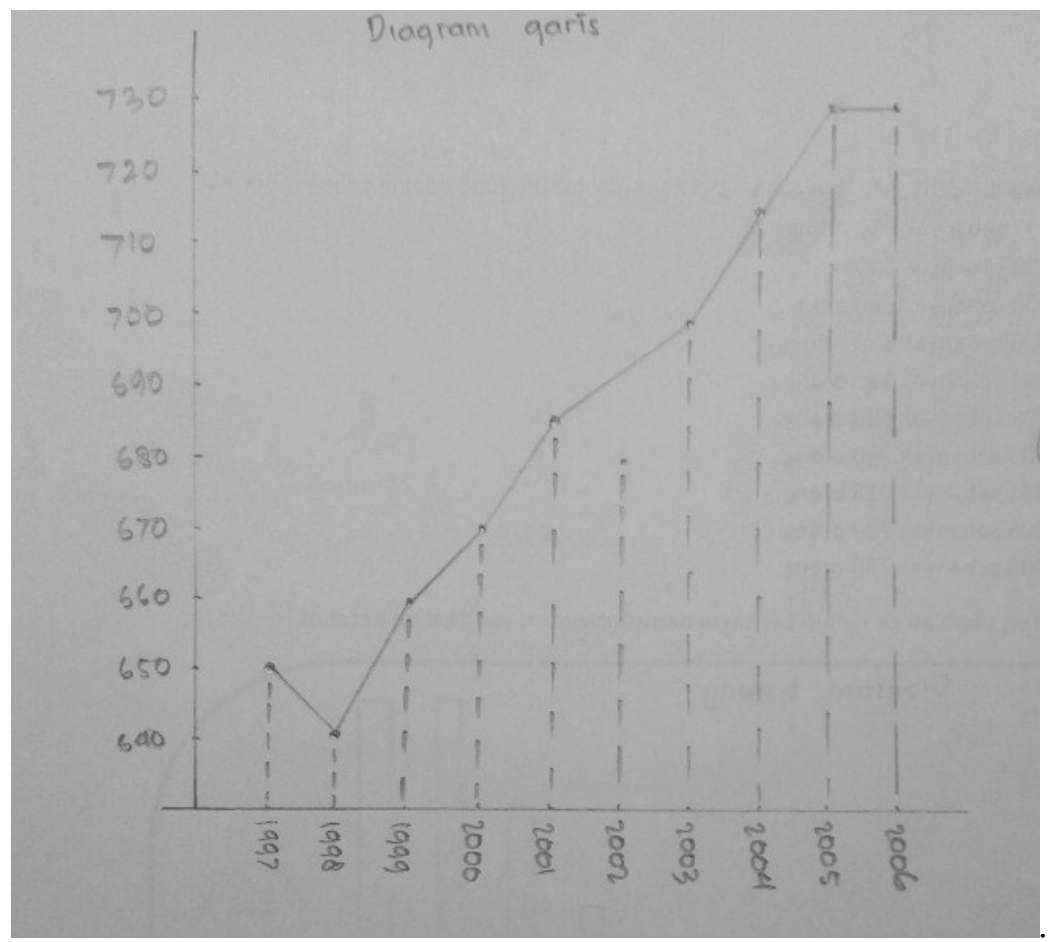

Gambar 3b. Jawaban siswa kelas Ekserimen yang mengerjakan menggunakan diagram garis. 


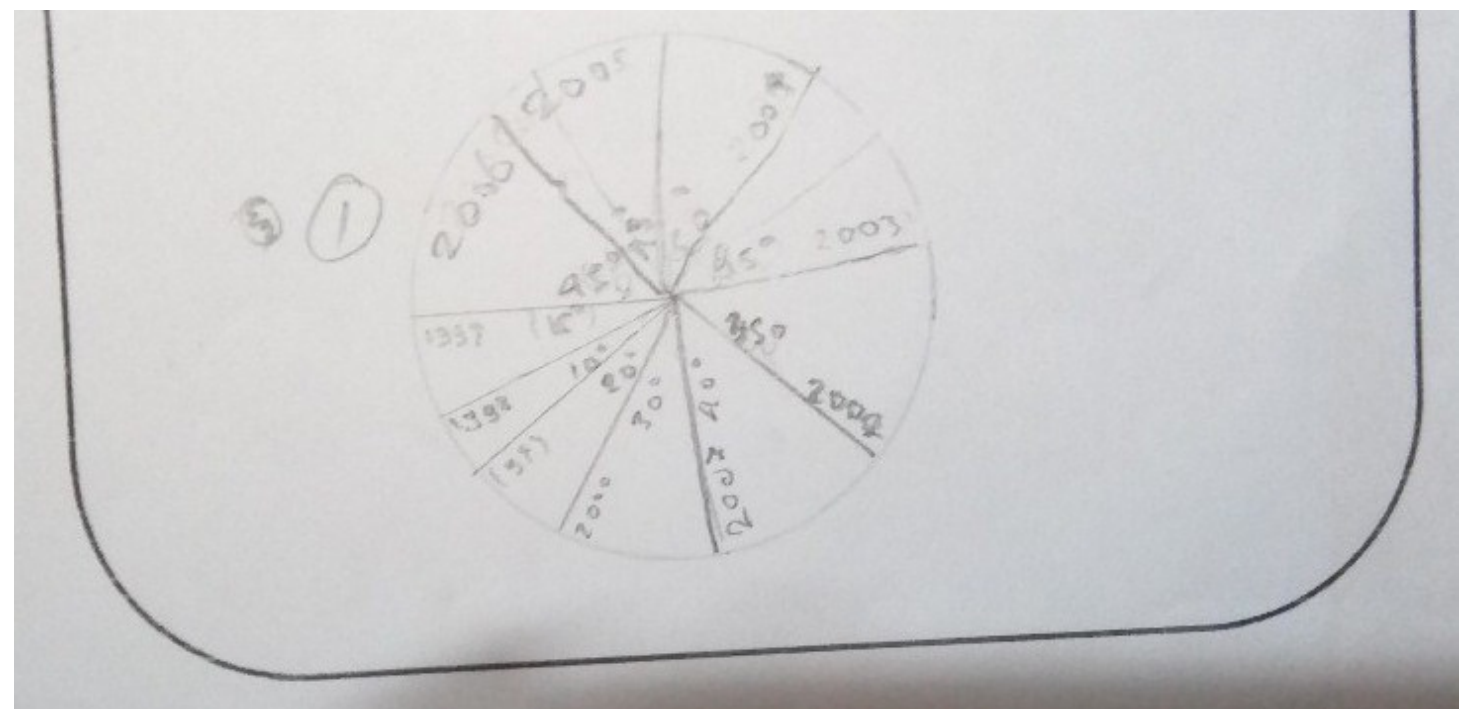

Gambar 3c. Jawaban siswa kelas Ekserimen yang mengerjakan menggunakan diagram lingkaran.

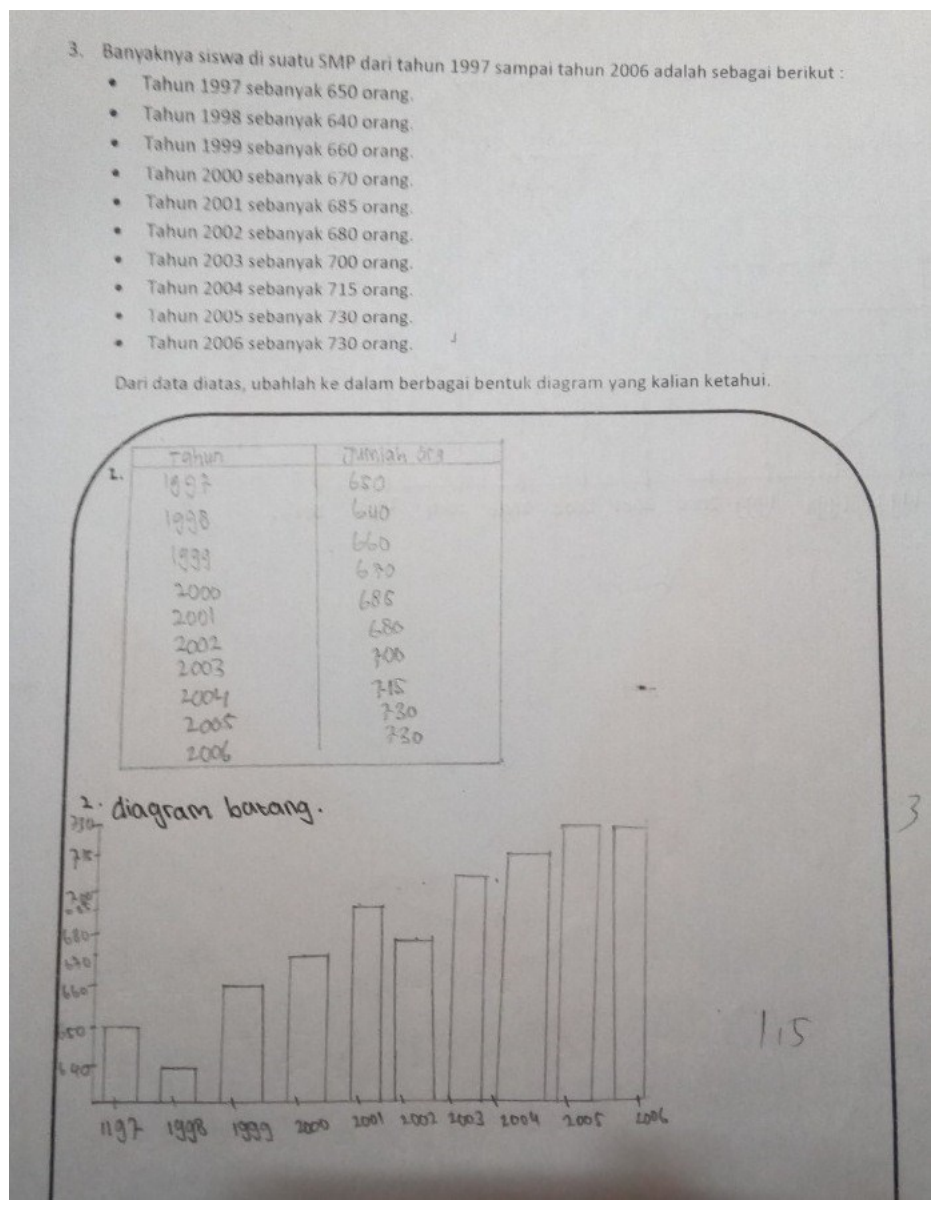

Gambar 3d. Jawaban siswa kelas Kontrol yang mengerjakan menggunakan diagram batang. 


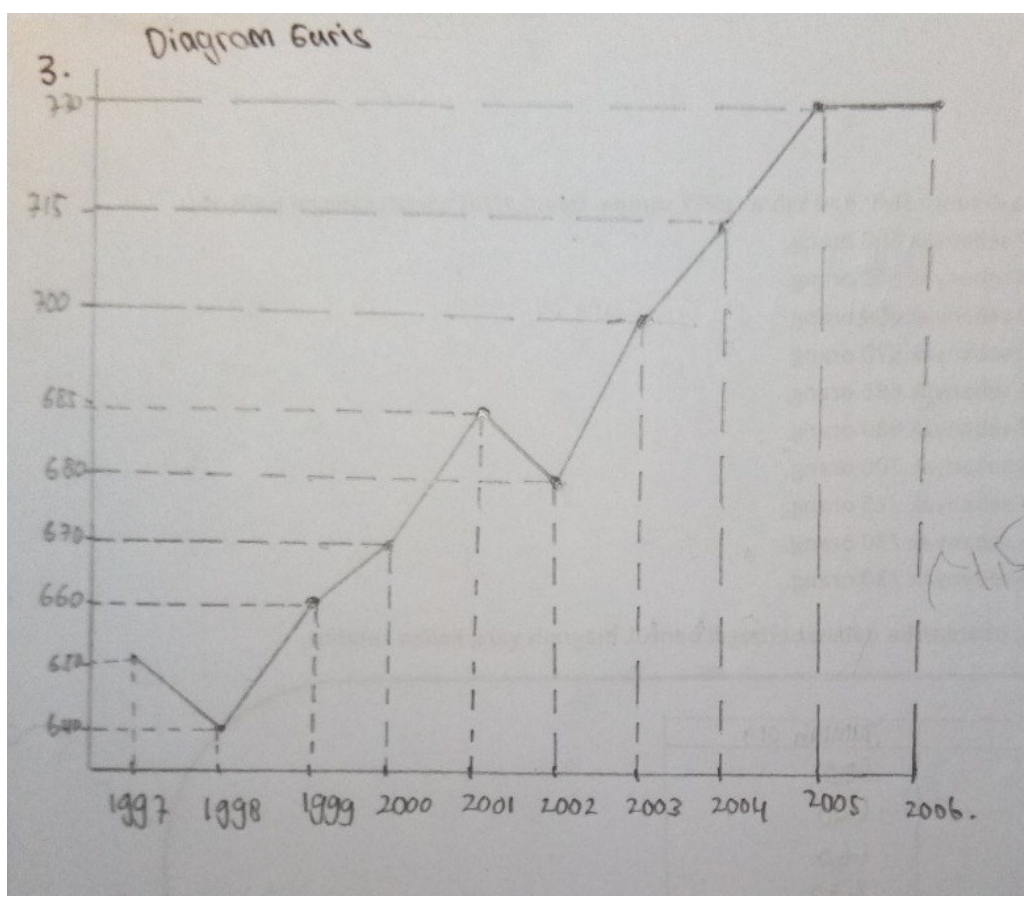

Gambar 3e. Jawaban siswa kelas Kontrol yang mengerjakan menggunakan diagram garis.

Pada gambar 3a, 3b, dan 3c jawaban salah satu siswa kelas Ekserimen tidak memiliki kesulitan untuk menentukan diagram batang (gambar 3a), dan diagram garis (gambar 3b). Pada diagram lingkaran (gambar 3c), masih terdapat banyak kesulitan yaitu pada cara menghitung besar sudut dan presentase yang salah dan kurang tepat sehingga menghasilkan diagram lingkaran yang salah. Sedangkan pada gambar 3d, dan gambar 3e, jawaban salah satu siswa kelas Kontrol, dalam menjawab pertanyaan nomor 3 ini, tidak ada kesulitan. Karena waktu yang tidak cukup membuat diagram batang dan diagram garisnya tidak rapi atau dalam menentukan jarak antara 1 angka ke angka lainnya tidak sama dan rentang amgkanya juga tidak sama. Di sisi lain, siswa kelas kontrol memiliki kemampuan berpikir kreatif untuk mencantumkan tabel sehingga mempermudah pengerjaan soal nomor 3 . Untuk siswa kelas kontrol tidak ada yang mengerjakan diagram lingkaran, karena kesulitan dalam menghitung besar sudut dan presentase.

\section{KESIMPULAN}

Dari hasil dan pembahasan maka, dapat di simpulkan bahwa kemampuan berpikir kreatif siswa yang menggunakan pembelajaran dengan pembelajaran RME (Realistic Matematics Education) lebih baik dari pada siswa yang menggunakan pembelajaran konvensional. Siswa dengan pembelajaran RME (Realistic Matematics Education) mendapatkan rata-rata nilai postes lebih tinggi dibandingkan siswa yang menggunakan pembelajaran konvensional. Selain itu, perbedaan pencapaian kemampuan berpikir kreatif siswa yang diberikan pembelajaran RME dengan siswa yang diberikan pembelajaran konvensional adalah siswa yang diberikan pembelajaran RME lebih baik dalam menerapkan rumus yang sudah dipelajari ke dalam soalsoal dibandingkan dengan siswa yang diberikan pembelajaran konvensional. siswa yang diberikan pembelajaran RME lebih baik dalam menerapkan aturan-aturan yang berlaku dalam penyelesaian soal-soal matematika, seperti dalam pembuatan diagram batang, diagram garis, dan diagram lingkaran dibandingkan dengan siswa yang diberikan pembelajaran konvensional. 


\section{DAFTAR PUSTAKA}

Andiyana, M. A., Maya, R., \& Hidayat, W. (2018). Analisis Kemampuan Berpikir Kreatif Matematis Siswa SMP Pada Materi Bangun Ruang. JPMI (Jurnal Pembelajaran Matematika Inovatif), 1(3), 239-248.

Choridah, D. T. (2016). Peran Pembelajaran Berbasis Masalah untuk Meningkatkan Kemampuan Komunikasi dan Berpikir Kreatif serta Disposisi Matematis Siswa SMA. Infinity Journal, 2(2), 194-202.

Hadi, S. (2017). Peer Review: Pendidikan Matematika Realistik-Teori, Pengembangan dan Implementasinya.

Hidayat, W. (2012). Meningkatkan Kemampuan Berpikir Kritis dan Kreatif Matematik Siswa SMA Melalui Pembelajaran Kooperatif Think-Talk-Write (TTW). In Seminar Nasional Penelitian, Pendidikan dan Penerapan MIPA.

Indraningtias, D. A., \& Wijaya, A. (2017). Pengembangan Perangkat Pembelajaran Berbasis Pendekatan Matematika Realistik Materi Bangun Ruang Sisi Datar Berorientasi pada Kemampuan Berpikir Kritis Siswa Kelas VIII SMP. Jurnal Pendidikan Matematika-S1, 6(5), 24-36.

Sumarmo, U., Hidayat, W., Zukarnaen, R., Hamidah, M., \& Sariningsih, R. (2012). Kemampuan dan Disposisi Berpikir Logis, Kritis, dan Kreatif Matematik (Eksperimen terhadap Siswa SMA Menggunakan Pembelajaran Berbasis Masalah dan Strategi Think-Talk-Write). Jurnal Pengajaran MIPA, 17(1), 17-33.

Wijayanti, S. (2017). Penggunaan Pendekatan Realistic Mathematics Education (RME) Sebagai Upaya Peningkatan Kreativitas Dalam Pemecahan Masalah Matematika Siswa Kelas X. 7 SMA Negeri 1 Pulokulon. MAGISTRA, 28(95). 